\title{
Skeletal muscle uncoupling protein 3 expression is a determinant of energy expenditure in Pima Indians.
}

Citation for published version (APA):

Schrauwen, P., Xia, J., Bogardus, C., Pratley, R. E., \& Ravussin, E. (1999). Skeletal muscle uncoupling protein 3 expression is a determinant of energy expenditure in Pima Indians. Diabetes, 48(1), 146-149. https://doi.org/10.2337/diabetes.48.1.146

Document status and date:

Published: 01/01/1999

DOI:

10.2337/diabetes.48.1.146

Document Version:

Publisher's PDF, also known as Version of record

Document license:

Taverne

\section{Please check the document version of this publication:}

- A submitted manuscript is the version of the article upon submission and before peer-review. There can be important differences between the submitted version and the official published version of record.

People interested in the research are advised to contact the author for the final version of the publication, or visit the DOI to the publisher's website.

- The final author version and the galley proof are versions of the publication after peer review.

- The final published version features the final layout of the paper including the volume, issue and page numbers.

Link to publication

\footnotetext{
General rights rights.

- You may freely distribute the URL identifying the publication in the public portal. please follow below link for the End User Agreement:

www.umlib.nl/taverne-license

Take down policy

If you believe that this document breaches copyright please contact us at:

repository@maastrichtuniversity.nl

providing details and we will investigate your claim.
}

Copyright and moral rights for the publications made accessible in the public portal are retained by the authors and/or other copyright owners and it is a condition of accessing publications that users recognise and abide by the legal requirements associated with these

- Users may download and print one copy of any publication from the public portal for the purpose of private study or research.

- You may not further distribute the material or use it for any profit-making activity or commercial gain

If the publication is distributed under the terms of Article $25 \mathrm{fa}$ of the Dutch Copyright Act, indicated by the "Taverne" license above, 


\title{
Skeletal Muscle Uncoupling Protein 3 Expression Is a Determinant of E nergy Expenditure in Pima Indians
}

\author{
Patrick Schrauwen, J ames Xia, Clifton Bogardus, Richard E. Pratley, and E ric Ravussin
}

\begin{abstract}
The recent discovery of uncoupling protein (UCP)-2 and UCP-3, and their high expression in skeletal muscle, has renewed interest in a possible role for these proteins in underlying the variability in energy expenditure and therefore metabolic efficiency. Using reverse transcription-polymerase chain reaction, levels of expression of UCP-2 and long and short forms of UCP-3 were measured in skeletal muscle of 19 nondiabetic, male Pima Indians covering a wide range of body weight. Twenty-four-hour energy expenditure was measured in a respiratory chamber in 16 of these individuals. BMI was negatively correlated with the expression levels of the long $(r=-0.53, P=0.025)$ and short ( $r=-0.46, P=0.047)$ forms of UCP-3. B MI was not correlated with UCP-2 expression. Metabolic rate during sleep, adjusted for fat-free mass and fat mass, was positively correlated with the long form of UCP-3 $(r=0.69$, $P=0.006)$. These results indicate that UCP-3 may be a determinant of energy expenditure and metabolic efficiency in Pima Indians. Dia betes 48:146-149, 1999
\end{abstract}

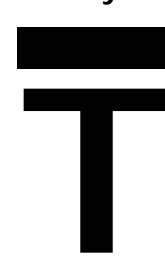

he development of obesity is characterized by an imbalance between energy intake and energy expenditure. Resting metabolic rate (RMR) comprises $50-80 \%$ of daily energy expenditure (1) and is quite variable among individuals, even after adjusting for differences in body weight and body composition (2). More importantly, the variability in RMR adjusted for fat-free mass, fat mass, age, and sex aggregates in families, suggesting genetic determinants $(3,4)$. In addition, a low adjusted RMR is a risk factor for weight gain (5). It is therefore important to understand the physiological mechanism(s) underlying the variability in RMR. Some of this variability has been shown to be associated with the variability in skeletal muscle metabolism (6).

In rodents, brown adipose tissue plays an important role in thermogenesis, via the activation of an uncoupling protein

From the Clinical Diabetes and Nutrition Section (J.X., C.B., R.P., E.R.), National Institute of Diabetes and Digestive and Kidney Diseases, National Institutes of Health, Phoenix, Arizona; and the Department of Human Biology (P.S.), Maastricht University, Maastricht, the Netherlands.

Address correspondence to Dr. Eric Ravussin, Director Obesity Research, Lilly Corporate Center, Drop Code 0545, Indianapolis, IN 46285. E-mail: eric ravussin@lilly.com. No reprints available.

Received for publication 27 J uly 1998 and accepted in revised form 24 September 1998.

E.R. is employed by Eli Lilly, but was not at the time of the study.

$b p$, base pair; RMR, resting metabolic rate; RT-PCR, reverse transcription-polymerase chain reaction; SMR, sleeping metabolic rate; UCP, uncoupling protein; UCP-3L, uncoupling protein 3 , long form; UCP-3S, uncoupling protein 3, short form. gene, Ucp-1. This uncoupling protein gene encodes for a mitochondrial protein carrier, which uncouples respiration from ATP production and stimulates heat production (7). Ucp-1 is only expressed in brown adipose tissue, which is scarce in adult humans and is not thought to play a major role in energy balance. Recently, two new uncoupling proteinsuncoupling protein-2 (UCP-2) $(8,9)$ and uncoupling protein3 (UCP-3) $(10,11)$ - were discovered. UCP-2 and UCP-3, which have $\sim 55 \%$ amino acid identity with uncoupling protein1 , have been shown to have uncoupling activity $(9,12)$. UCP2 is widely distributed in a variety of tissues, whereas UCP3 is mainly expressed in skeletal muscle $(10,11)$. These new UCPS are likely candidates to underlie the variability in energy metabolism in humans and may be involved in the development of obesity.

UCP-2 was mapped to chromosome 11q13 (9) and UCP-3 is thought to be only $8 \mathrm{~kb}$ away (D. Ricquier, personal communication). In the Quebec Family study, RMR was genetically linked to DNA microsatellite markers in the vicinity of $11 q 13$ (13) . UCP-3 is expressed in a long (UCP-3L) and a short form (UCP-3S), with the latter lacking exon 7, likely resulting in a truncated protein (14). It is unknown whether this difference is functionally important, although this $\mathrm{COOH}$-terminal region ( 37 amino acids) is thought to contain a nucleotide binding region.

In the present study, we investigated the relationship between UCP-2 and UCP-3 expression in skeletal muscle and obesity/energy metabolism in nondiabetic Pima Indians.

\section{RE SE ARCH DESIGN AND METHODS}

Subjects. A total of 19 male nondiabetic Pima Indians were studied. Sixteen of them also had 24-h energy expenditure measured in a respiratory chamber (1). The characteristics of this group are given in Table 1. All subjects were in good health as determined by physical examination and routine blood and urine tests. All subjects were clinically euthyroid, and their concentrations of serum thyroidstimulating hormone were within the normal range (Table 1). None took prescribed or over-the-counter medications. This study was approved by the ethics committee of the National Institute of Diabetes and Digestive and Kidney Diseases and by the Tribal Council of the Gila River Indian Community, and all subjects gave written informed consent before participation. Subjects were admitted to the Clinical Research Unit for 7-10 days and were provided a standard weight-maintaining diet containing $50 \%$ carbohydrates, $30 \%$ fat, and $20 \%$ protein for at least 3 days before metabolic testing. Glucose tolerance was assessed by an oral glucose tolerance test according to World Health Organization criteria (15), and insulin concentrations were also measured (Concept 4; ICN, Costa Mesa, CA).

Body composition and energy metabolism. Percent total body fat was measured by dual-energy X-ray absorptiometry using a total body scanner (DPX-L; Lunar Radiation Corp, Madison, WI), as previously described (16). After at least 3 days on a weight-maintenance diet, subjects entered the respiratory chamber at 7:30 A.M. for a 23-h stay (1). Sleeping metabolic rate (SMR) was calculated between 11:00 P.M. and 5:00 A.M., using all 15-min periods during which spontaneous physical activity was detected $<1.5 \%$ of the time by 2 microwave motion detectors (1). Muscle biopsy and RNA analysis. After subjects had at least 7 days on a weight-maintenance diet, a percutaneous muscle biopsy was taken from the vas- 
TABLE 1

Subject characteristics, energy expenditure, and UCP-2/3 expression in 19 nondiabetic Pima Indians

Age (year)

Height $(\mathrm{m})$

Weight $(\mathrm{kg})$

BMI $\left(\mathrm{kg} / \mathrm{m}^{2}\right)$

Body fat (\%)

Fasting insulin ( $\mathrm{pmol} / \mathrm{l})$

Thyroid-stimulating hormone ( $\mathrm{mU} / \mathrm{l}$ )

24-h energy expenditure

(kJ/day)*

SMR (kJ/day)*

UCP-2 mRNA expression

(ratio with $\beta$-actin)

UCP-3L mRNA expression

(ratio with $\beta$-actin) $\dagger$

UCP-3S mRNA expression

(ratio with $\beta$-actin)

Total UCP-3 mRNA expression

(ratio with $\beta$-actin)†

UCP-3S/UCP3L†

Data are means \pm SD (range). $* n=16 ; \uparrow n=18$.

tus lateralis muscle after an overnight fast. After local anesthesia, a 5-mm diameter side-cutting needle was passed through a 7-mm skin incision. Muscle specimens were immediately homogenized in denaturation solution, and total RNA was isolated (Ambion, Austin, TX). Oligo-dT-primered cDNAs were synthesized from $2 \mu \mathrm{g}$ of total RNA in a $20 \mu \mathrm{l}$ volume using SuperScript cDNA synthesis kit from Gibco BRL (Gaithersburg, MD). The integrity of each RNA sample was verified by gel electrophoresis. For quantitative comparisons, reverse transcription-polymerase chain reaction (RT-PCR) was performed. All primer combinations were designed to span at least one intron to avoid co-amplification of genomic DNA, which may contaminate the RNA preparation. For UCP-2, a 964-base pair (bp) cDNA fragment was obtained using $5^{\prime}$-catctcctgggacgtag- ${ }^{\prime}$ as a sense and $5^{\prime}$-atcaggtcagcagcaggagag- $3^{\prime}$ as an antisense primer. A 993-bp UCP-3L CDNA fragment was obtained using $5^{\prime}$-aggactatggttggactgaa- 3 ' as a sense primer and $5^{\prime}$-cattcttaactggtttcggacac- $3^{\prime}$ as an antisense primer. These primers are in exon 2 and exon 7, respectively. For UCP-3S, a 868-bp CDNA fragment was obtained using the same sense primer as in UCP-3L, and an antisense $5^{\prime}$-gttctctgggagggagtgc-3' primer, which is in the untranslated region of exon 6. A 535-bp fragment of the $\beta$-actin gene was co-amplified as an internal control. Aliquots $(5 \mu \mathrm{l})$ were taken from each tube every four cycles after 22 cycles to determine whether the amplification was in the exponential phase for each product. The products were resolved on a $1 \%$ agarose gel containing $1 \mu \mathrm{l}$ ethidium bromide, which was photographed using Polaroid 665 film (Cambridge, MA), and the relative concentration of PCR products was measured by scanning densitometry (Biol mage version 3.3; Sun SparcStation 5, Ann Arbor, MI). Each experiment was performed in triplicate, and the mean value was calculated for analysis. Levels of mRNA were expressed as the ratio of signal intensity for the target genes relative to $\beta$-actin and were corrected for the size of the product. Total UCP-3 expression was calculated by summing the corrected ratios for UCP-3L and UCP-3S. For determination of the ratio of UCP-3S:UCP-3L, the target genes were amplified together without the control gene $\beta$-actin.

Statistical analysis. All data were analyzed using the procedures of the SAS Institute (Cary, NC). Metabolic rate (sleeping or over $24 \mathrm{~h}$ ) was adjusted by linear regression model for the independent effects of fat-free mass and fat mass. Pearson correlation coefficients were calculated to determine the relationship between selected variables. Because of the small number of subjects, Spearman correlation coefficients were also calculated to confirm the significance of correlations. Multiple regression models also assessed the effect of UCP-2 and UCP-3 expression, independent of fat-free mass and fat mass, on energy metabolism. Data are expressed as means $\pm \mathrm{SD}$, and $\mathrm{P}$ values $<0.05$ are considered significant.

\section{RESULTS}

The mean levels of expression of UCP-2, UCP-3L, UCP-3S, total UCP-3, and ratio of UCP-3S/UCP-3L are given in Table
1. The expression of UCP-3L correlated with the expression of UCP-3S ( $r=0.60, P<0.01)$. The ratio of UCP-3S to UCP$3 \mathrm{~L}$ mRNA expression did not correlate with any of the measured variables.

$\mathrm{BMI}$ was negatively correlated with UCP-3L $(r=-0.53, \mathrm{P}$ $=0.025$, Fig. 1), UCP-3S ( $r=-0.46, P=0.047)$, and total UCP$3(r=-0.56, P=0.017)$. BMI was not correlated with UCP-2. Percent body fat tended to correlate negatively with UCP-3L $(r=-0.42, P=0.09)$, UCP-3S $(r=-0.40, P=0.09)$, and total UCP-3 ( $r=-0.46, P=0.06)$, but not with UCP-2 . Fasting plasma insulin concentration was correlated negatively with UCP-3L $(r=-0.53, P=0.04)$ and only tended to correlate with total UCP-3 $(P=0.09)$. None of the UCPs were correlated with thyroid-stimulating hormone concentration.

Twenty-four-hour energy expenditure and SMR were adjusted for their two major determinants, fat-free mass and fat mass. Adjusted SMR was positively correlated with UCP3L $(r=0.69, P=0.006, F i g .1)$ and total UCP-3 $(r=0.60, P=$ 0.02 ), but not with UCP-2 expression. Twenty-four-hour
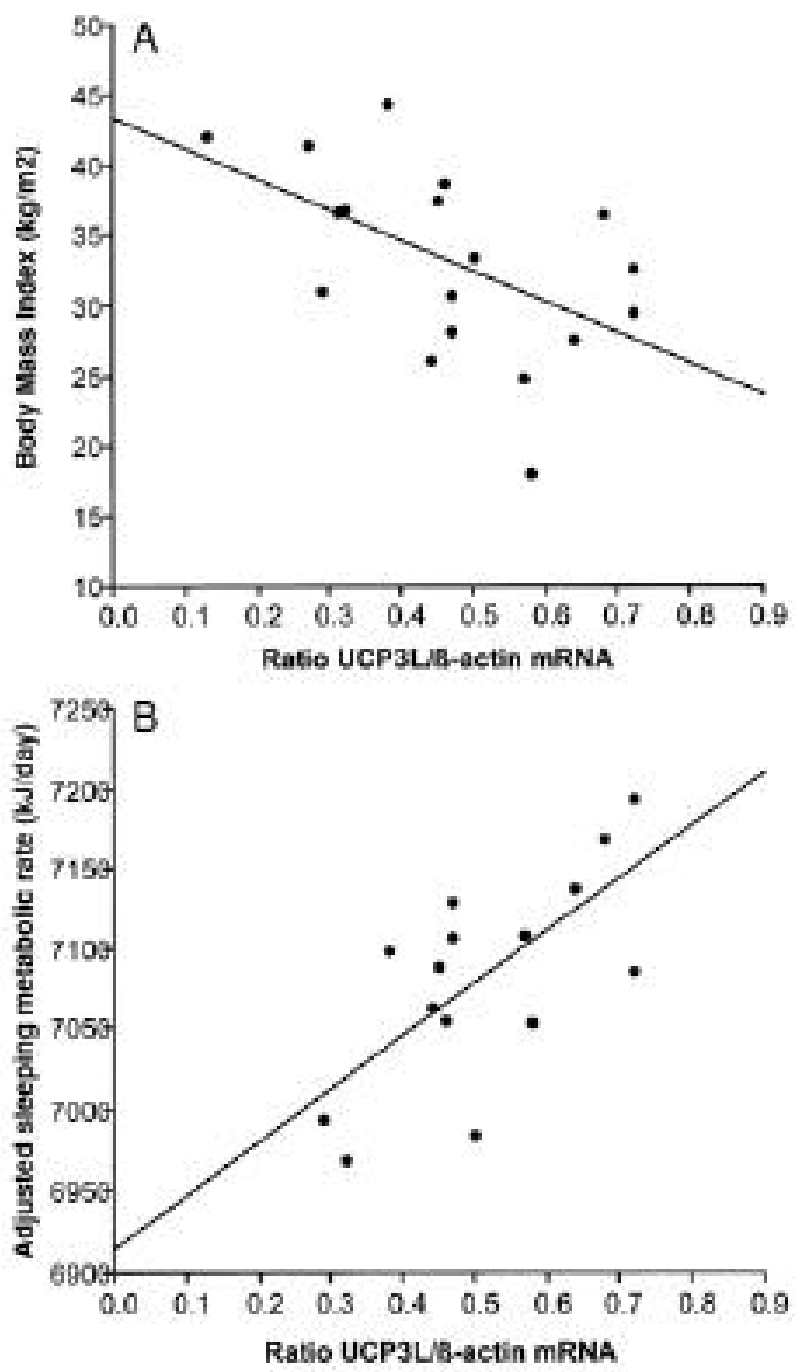

FIG. 1. Relationship between BMI (A) and SMR (B) and relative UCP3L mRNA expression (UCP-3L/ $\beta$-actin) in skeletal muscle determined by RT-PCR. The mRNA expression is the mean of triplicate measurements. A: B MI $(r=-0.53, P=0.025)$. B : SMR $(r=0.69, P=0.006)$. SMR is adjusted for fat-free mass and fat mass. 
energy expenditure only tended to correlate with total UCP$3(P=0.07)$.

\section{DISCUSSION}

RMR is an important determinant of 24-hour energy expenditure, accounting for $\sim 50-80 \%$ of daily energy expenditure (1). The major determinants of RMR are fat-free mass, fat mass, and sex, but even after adjustment for these factors there is still considerable variability between individuals. It is important to understand the determinants of this variability, because a low "relative" metabolic rate is a predictor of weight gain (5). Part of the remaining variability in RMR can be accounted for by differences in skeletal muscle metabolism (6). The recently discovered mitochondrial proteins UCP-2 $(8,9)$ and UCP-3 $(10,11)$ are both expressed in skeletal muscle and have been shown to have uncoupling activity, thereby dissipating energy as heat. Therefore, these UCPs are likely candidates to underlie the physiological variability in resting energy expenditure in humans. In this study, we found positive correlations between SMR, adjusted for fatfree mass and fat mass, and the expression of the UCP-3 gene, which indicates that UCP-3 may be a determinant of energy expenditure in humans.

Recently, Walder et al. (17) reported an association between polymorphisms in UCP-2 and SMR in Pima Indians. UCP-3 is located in the same BAC and P1 clones as UCP-2 (14), indicating that the two genes are physically near each other. Therefore, it is possible that the association between UCP-2 polymorphisms and SMR might be due to variants in UCP-3. In this study, we found a positive correlation between SMR and UCP-3 mRNA levels. Assuming that mRNA levels reflect UCP-3 protein concentrations, these data indicate that reduced skeletal muscle UCP-3 results in a low SMR. Interestingly, Barbe et al. ( 18) recently reported a positive correlation between RMR and UCP-2 expression in adipose tissue of obese women after 25 days on a very-low-calorie diet. Because a low relative RMR is a predisposing factor for weight gain (5), it is expected that individuals with low UCP2 and/or UCP-3 gene expression would eventually have higher body weight. Only prospective studies in humans will tease out the cause-and-effect relationship between UCP-3 gene expression and body weight gain. Alternatively, transgenic animal models in which UCP-3 expression is absent or upregulated will provide information on the role of UCP-3 as a determinant of metabolic rate and obesity.

The negative correlation between skeletal muscle UCP-3 expression and BMI in Pima Indians is in contrast with the results of Millet et al. (19), who found no difference in UCP-3 mRNA expression in skeletal muscle between obese and lean Caucasians. In Pima Indians, the prevalence of obesity is higher than in Caucasians, probably because of a stronger genetic susceptibility. The lack of correlation between BMI and UCP-3L in Caucasians might be explained by a lower susceptibility to obesity in this population but does not rule out a role for UCP-3 in energy expenditure and obesity in Caucasians.

UCP-3 is expressed as a long and a short form. UCP-3S lacks exon 7, which encodes for a domain that is highly homologous to $\mathrm{COOH}$-terminal residues found in UCP-1 and UCP-2 (14). In UCP-1, this terminal region is believed to participate in purine nucleotide-mediated inhibition of uncoupling activity (20). This suggests that UCP-3S might have altered uncoupling activity. In the present study, UCP-3L and
UCP-3S were equally expressed in skeletal muscle, confirming previous results (14). There was, however, some variability in the ratio between UCP-3S and UCP-3L expression among individuals, but this ratio was not related to any of the measured variables.

Fasting insulin concentration was negatively correlated with UCP-3L expression. This relation is unlikely to be due to a direct effect of insulin, as acute hyperinsulinemia does not appear to alter the expression of UCP-3 in skeletal muscle (19). B ecause fasting insulin concentrations are related to $\mathrm{BMI}$ and percent body fat, it is possible that UCP-3L expression and insulin concentrations were related through their common association with obesity. However, it is also possible that UCP-3 or a closely linked gene directly affects insulin. In support of this, Ucp-2 was linked to hyperinsulinemia in mice (9), and the region containing UCP-2/UCP-3 showed some evidence of linkage to 2 -h insulin concentrations during an oral glucose tolerance test in nondiabetic Pima Indians (21).

The cause(s) of the two- to threefold variation in skeletal muscle UCP-3 mRNA expression in Pima Indians remains to be determined. Uqp-3 mRNA concentrations are increased by thyroid hormones (12), leptin (12), $\beta 3$ agonists (12), glucocorticoids (12), and free fatty acids (22). Whether these factors or DNA polymorphisms in, or near, the UCP-3 gene result in differential expression of UCP-3 mRNA remains to be determined.

In conclusion, our results indicate that UCP-3 mRNA expression in skeletal muscle varies two- to threefold and may be a determinant of the variability in rates of energy expenditure and, thereby, in the degree of obesity. Additional studies are needed to demonstrate that UCP-3 protein concentrations are reflected by UCP-3 mRNA concentrations and that UCP-3 protein concentrations are also correlated with rates of energy expenditure. Also, the genetic and/or other hormonal and metabolic determinants of variations in skeletal muscle UCP-3 mRNA and protein concentrations in Pima Indians need to be identified.

\section{ACKNOWLE DGMENTS}

P.S. was supported by a grant from the Netherlands Organization for Scientific Research (NWO).

We thank Chris Wiedrich for isolation of RNA from muscle biopsies and Mike Milner for technical assistance. Most of all, we thank the Pima Indian volunteers from the Gila River Indian Community: without their willing cooperation and participation, these studies would not have been possible.

\section{RE FERE NCES}

1. Ravussin E, Lillioja S, Anderson TE, Christin L, Bogardus C: Determinants of 24-hour energy expenditure in man: methods and results using a respiratory chamber. J Clin Invest 78:1568-1578, 1986

2. Tataranni PA, Ravussin E: Variability in metabolic rate: biological sites of regulation. Int J Obesi ty 19:S102-S106, 1995

3. Bogardus C, Lillioja S, Ravussin E, Abbott W, Zawadzki J K, Young A, Knowler WC, J acobowitz R, Moll PP: Familial dependence of the resting metabolic rate. New Engl J Med 315:96-100, 1986

4. Bouchard C, Tremblay A, Nadeau A, Després JP, Thériault G, Boulay MR, Lortie $G$, Leblanc C, Fournier G: Genetic effect in resting and exercise metabolic rate. Metabolism 38:364-370, 1989

5. Ravussin E, Lillioja S, Knowler WC, Christen L, Freymond D, Abbott WGH, Boyce V, How ard BV, Bogardus C: Reduced rate of energy expenditure as a risk factor for body-weight gain. N Engl J Med 318:467-472, 1988

6. Zurlo F, Larson K, Bogardus C, Ravussin E: Skeletal muscle metabolism is a major determinant of resting energy expenditure. J Clin Invest 86:1423-1427, 1990 
7. Ricquier D, Casteilla L, B ouillaud F: Molecular studies of the uncoupling protein. FASEB J 5:2237-2242, 1991

8. Gimeno RE, Dembski M, Weng X, Deng N, Shyjan AW, Gimeno CJ, Iris F, Ellis SJ , Woolf EA, Tartaglia LA: Cloning and characterization of an uncoupling protein homolog: a potential molecular mediator of human thermogenesis. Dia betes 46:900-906, 1997

9. Fleury C, Neverova M, Collins S, Raimbault S, Champigny O, Levi-Meyrueis C, B ouillaud F, Seldin MF, Surwit RS, Ricquier D, Warden CH: Uncoupling protein-2: a novel gene linked to obesity and hyperinsulinemia. Nat Genet 15:269-273, 1997

10. Boss O, Samec S, Paoloni-Giacobino A, Rossier C, Dulloo A, Seydoux J, Muzzin $P$, Giacobino J -P: Uncoupling protein-3: a new member of the mitochondrial carrier family with tissue-specific expression. FEBS Lett 408:39-42, 1997

11. Vidal-Puig A, Solanes G, Grujic D, Flier J S, Lowell BB: UCP3: an uncoupling protein homologue expressed preferentially and abundantly in skeletal muscle and brown adipose tissue. Bi ochem Bi ophys Res Commun 235:79-82, 1997

12. Gong D-W, He Y, Karas M, Reitman M: Uncoupling protein-3 is a mediator of thermogenesis regulated by thyroid hormone, $\beta 3$-adrenergic agonists, and leptin. J Bi ol Chem 272:24129-24132, 1997

13. Bouchard C, Pérusse L, Chagnon YC, Warden G, Ricquier D: Linkage between markers in the vicinity of the uncoupling protein 2 gene and resting metabolic rate in humans. Hum Mol Genet 6:1887-1889, 1997

14. Solanes G, Vidal-Puig A, Grujic D, Flier J S, Lowell BB: The human uncoupling protein-3 gene: genomic structure, chromosomal localization, and genetic basis for short and long form transcripts. J Biol Chem 272:25433-25436, 1997

15. WHO Study Group: Preventi on of Di abetes Mellitus. Geneva, World Health Organization, 1994 (WHO Tech. Rep. Ser. 727)
16. Tataranni PA, Ravussin E: Use of dual X-ray absorptiometry in obese individuals. Am J Clin Nutr 55:730-734, 1995

17. Walder K, Norman RA, Hanson RL, Schrauwen P, Neverova M, Jenkinson CP, Easlick J, Warden CH, Pecqueur C, Raimbault S, Ricquier D, Harper M, Silver K, Shuldiner AR, Solanes G, Lowell BB, Chung WK, Leibel RL, Pratley R, Ravussin E: Association between uncoupling protein polymorphisms (UCP2UCP3) and energy metabolism/obesity in Pima Indians. Hum Mol Genet 7:1431-1435, 1998

18. Barbe P, Millet L, Larrouy D, Galitzky J, Berlan M, Louvet J-P, Langin D: Uncoupling protein-2 messenger ribonucleic acid expression during verylow-calorie diet in obese premenopausal women. J Clin Endocrinol Metab 88:2450-2453, 1998

19. Millet L, Vidal H, Andreelli F, Larrouy D, Riou J -P, Ricquier D, Laville M, Langin $D$ : Increased uncoupling protein-2 and -3 mRNA expression during fasting in obese and lean humans. J Cli n Invest 100:2665-2670, 1997

20. Bouillaud F, Arechage I, Petit PX, Raimbault S, Levi-Meyrueis C, Casteilla L, Laurent M, Rial E, Ricquier D: A sequence related to a DNA recognition element is essential for the inhibition by nucleotides of proton transport through the mitochondrial uncoupling protein. EMBO 13:1990-1997, 1994

21. Pratley RE, Thompson DB, Prochazka M, Baier L, Mott D, Ravussin E, Sakul H, Ehm MG, Burns DK, Foroud T, Garvey WT, Hanson RL, Knowler WC, Bennett PH, Bogardus C: An autosomal genomic scan for loci linked to pre-diabetic phenotypes in Pima Indians. J Clin Invest 101:1757-1764, 1998

22. Weigle DS, Selfridge LE, Schwartz MW, Seeley RJ, Cummings DE, Havel PJ, Kuijper J L, BertrandelRio H: Elevated free fatty acids induce uncoupling protein 3 expression in muscle: a potential explanation for the effect of fasting. Diabetes 47:298-302, 1998 
Author Queries (please see $Q$ in margin and underlined text)

Q1: Please check that author affliations are correct.

Q2: To distinguish between the UCP genes and the UCP proteins, please check carefully that when referring to the gene, the abbreviations are italicized. When referring to the protein, the abbreviations should not be italicized. Also, please check capitalization of the abbreviations, as a few are in the format $U c p$. Are these different from those formatted UCP? Q3: Please provide all author names (last name and first initial[s]) for personal communication.

Please define "kb."

Do you have any updated information for Ref. 21? 